\title{
Verification of the cylindrical tank shell stability using the stress design and the MNA-LBA procedure
}

\author{
Kamil Stowiński \\ kamil.slowinski@polsl.pl | (0) https://orcid.org/0000-0002-4225-520X \\ Chair of Building Structures, Faculty of Civil Engineering, Silesian University of \\ Technology in Gliwice \\ Marek Piekarczyk \\ matop@wp.pl | @ https://orcid.org/0000-0003-0566-4749 \\ Chair of Bridge, Metal and Timber, Faculty of Civil Engineering, Cracow \\ University of Technology \\ Mateusz Król \\ matkrol95@gmail.com
}

Scientific Editor: Andrzej Winnicki, Cracow University of Technology Technical Editor: Matgorzata Mazur, Cracow University of Technology Press Language Editor: Timothy Churcher, Merlin Language Services

Typesetting: Matgorzata Murat-Drożyńska, Cracow University of Technology Press

Received: November 2, 2021

Accepted: November 26, 2021

Copyright: @ 2021 Stowiński, Piekarczyk, Król. This is an open access article distributed under the terms of the Creative Commons Attribution License, which permits unrestricted use, distribution, and reproduction in any medium, provided the original author and source are credited.

Data Availability Statement: All relevant data are within the paper and its Supporting Information files.

Competing interests: The authors have declared that no competing interests exist.

Citation: Stowiński, K., Piekarczyk, M., Król, M. (2021). Verification of the cylindrical tank shell stability using the stress design and the MNA-LBA procedure. Technical Transactions, e2021021. https:// doi.org/10.37705/TechTrans/e2021021

\begin{abstract}
The article presents the course and results of the procedure for verifying the stability of the cylindrical shell of an oil tank with a floating roof, under wind load. Two dimensioning methods recommended by standard PN-EN 1993-1-6 were used, i.e. dimensioning based on the stress state and the MNA-LBA procedure. The method of determining the critical buckling resistance ratio from the linear bifurcation analysis (LBA) and the plastic reference resistance ratio from the physically nonlinear analysis (MNA) has been presented. Comparison of the results obtained with the use of the indicated design methods revealed significant discrepancies in the stress intensity levels of the analysed shell. When using the stress-based dimensioning method, it was shown that the buckling strength was exceeded by $33 \%$, while the results of the MNA-LBA procedure indicated a $33 \%$ reserve of the capacity of the analysed system.
\end{abstract}

Keywords: MNA-LBA procedure, steel tank, buckling, plastic collapse, wind load 


\section{Introduction}

Stability of steel shells of cylindrical tanks can be verified by using results obtained from numerical methods of the global analysis as specified in the standard PN-EN 1993-1-6. The procedure MNA-LBA is of specific importance among these methods. This procedure is based on results obtained from the materially non-linear analysis (MNA) and the linear bifurcation analysis (LBA). The application of this procedure in the design gives less conservative results when compared to the stress design and, on the other hand, is by far less laborious than the advanced methods of the global analysis, such as GMNIA (geometrically and materially non-linear analysis with imperfections) (Rotter, 2011; Iwicki, Tejchman, Chróścielewski, 2014). For some reasons, including the above ones, the MNA-LBA design procedure is recommended by the ECCS guidelines (ECCS, 2008) as the principal method for verifying the stability of cylindrical steel shells.

Despite its advantages mentioned above, the MNA-LBA procedure is rather rarely used in designing cylindrical tanks as the stress design is predominating. This situation can be explained by, inter alia, the insufficient transfer of knowledge from the science to the industry, including a lack of reference documents presenting the course and results of analyses performed with various types of the design methods. The authors have no knowledge on any public available document on comparing the practical use of the MNA-LBA procedure and results obtained from the stress design.

This paper describes the course and results of the procedure used to verify the stability of the floating roof tank shell for petroleum, using the stress design and the MNA-LBA procedure. It presents fundamental assumptions of both design methods and indicates the most difficult issues of their application. Finally, these methods were compared and the obtained results were discussed. This paper contains the results presented in the diploma thesis (Król, 2021).

\section{Analysed item and computational model}

The vertical-axis cylindrical tank shell with the stepwise variable wall thickness was used for the analysis. The tank geometry was taken on the basis of the general public educational drawings found in the paper (Żyburtowicz, 1966) with a slightly modified diameter and height of the shell. The final analysed values were: diameter of the shell midsuface $D=36280 \mathrm{~mm}$, height $H=16533 \mathrm{~mm}$ composed of eleven rings (segments) with a wall thickness $t$ varying from $6 \mathrm{~mm}$ to $22 \mathrm{~mm}$ (Fig. 1). The shell had stiffening rings acc. to (PN-EN 14015, 2010), that is, the primary wind girder and the secondary stiffening ring placed on the segments No. 11 and 9 respectively. Fig. 1 illustrates cross-sections of these rings. All shell elements were assumed to be made of structural steel S235 in accordance with (PN-EN 1993-1-1, 2006).

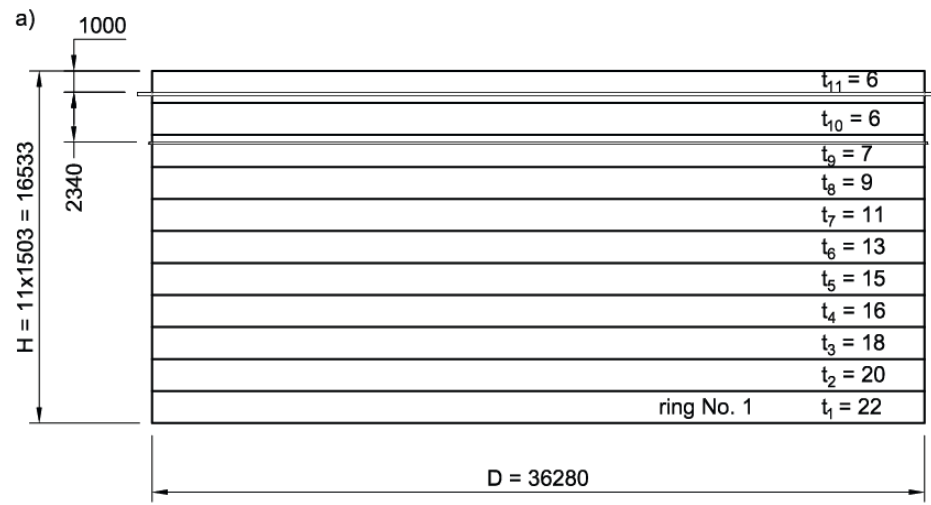

b)

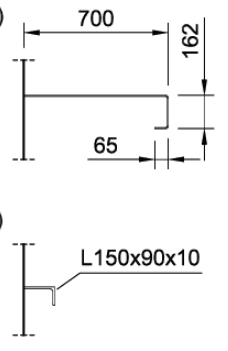

Fig. 1. Geometrical parameters of: a) the tank shell, b) primary wind girder, c) secondary stiffening ring (in $\mathrm{mm}$ ) (own study) 
The numerical model of the tank shell was designed in the Ansys software. Only half of the cylinder was simulated (Fig. 2) due to the structure symmetry and loads; however the adequate support conditions for the shell and stiffening ring edges were provided reflecting the symmetry conditions for the shell. The shell and the stiffening rings were modelled using the shell finite elements. The square finite elements with a side dimension of ca. $250 \mathrm{~mm}$ were layered on the shell. The rectangular finite elements were generated on the stiffening ring and had the side dimensions which ensured the relevant quality of the grid. The Young's modulus $E=210 \mathrm{GPa}$ and Poisson's ratio $v=0.3$ were used for the material models. An elastic-perfectly plastic model with the yield point $f_{\mathrm{y}}=235 \mathrm{MPa}$ was defined for the purpose of the MNA procedure. The shell was loaded with dead load and the wind pressure of non-linear distribution over the perimeter, which was defined in accordance with (PN-EN 1993-4-1, 2009) (Fig. 2). These load values were taken into account as part of the combination of calculations created in accordance with the equation $6.10 \mathrm{~b}$ from the standard (PN-EN 1990, 2004).

a)

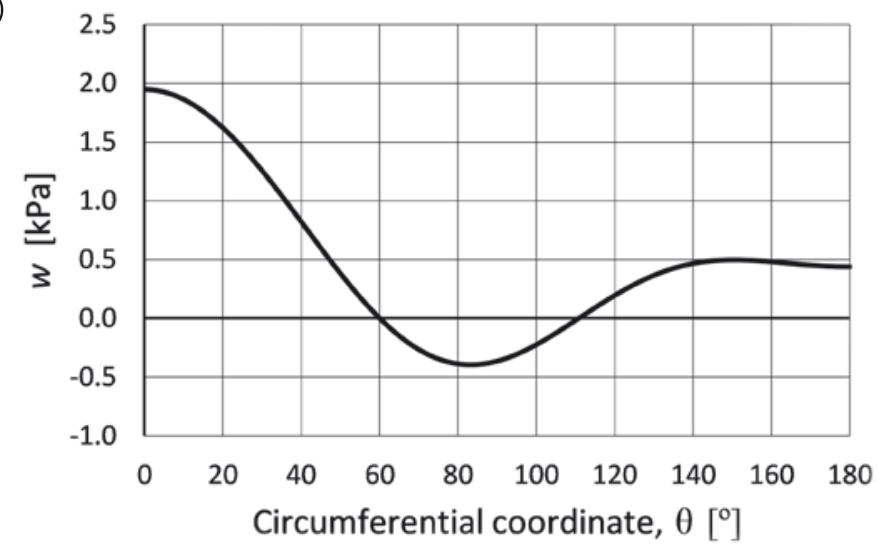

b)

Fig. 2. Pattern of the design wind pressure acting on the tank shell (positive values mean pressure): a) determined according to (PN-EN 1993-4-1, 2009), b) implemented in numerical model (own study)

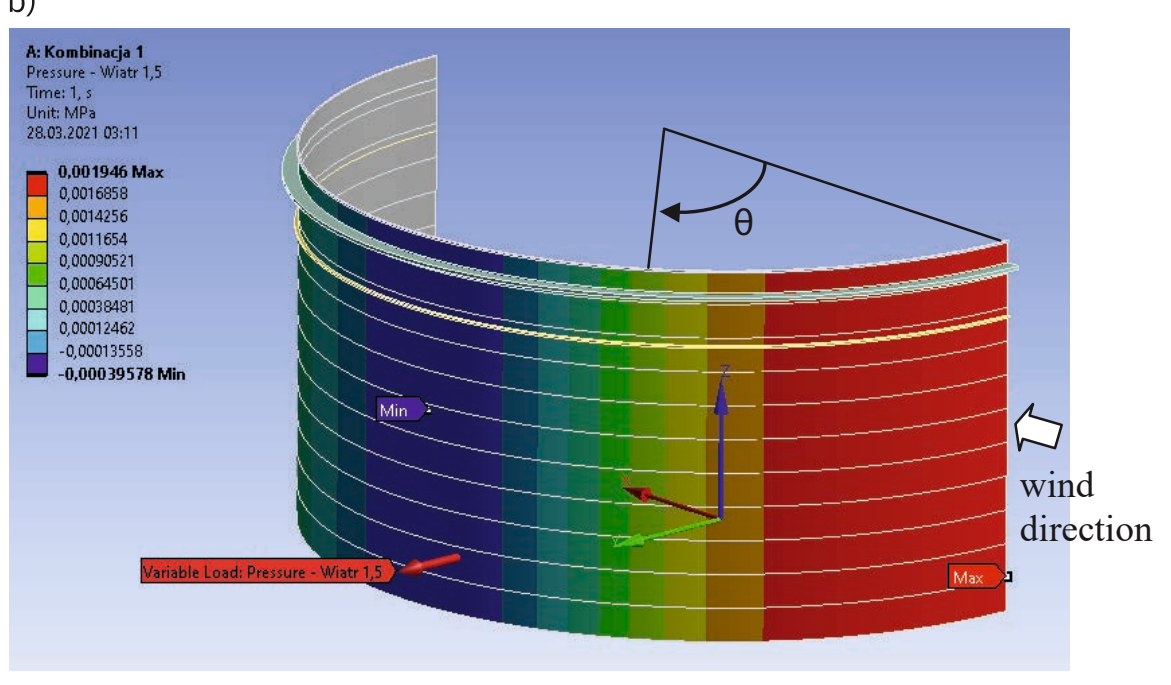

\section{Stability verification using the stress criterion}

The procedure for verifying stability using the stress design is specified in the standard(PN-EN1993-1-6,2009) as partof controllingthebucklinglimitstateLS3. This procedure consists in demonstrating that design values of the so-called key membrane stresses determined from the linear elastic analysis (LA) do not overcome the relevant design resistance of the shell. The stability conditions are verified separately for membrane stresses which are normal compressive 
stresses in the meridional $\sigma_{\mathrm{x}, \mathrm{Ed}}$ and circumferential $\sigma_{\theta, \mathrm{Ed}}$ directions, shear stresses $\tau_{\mathrm{x} \theta \text {,Ed}}$, and also in interactions of the stress state components. Considering buckling of the thin-wall tank shell, circumferential stresses $\sigma_{\theta, \mathrm{Ed}}$, which are caused by wind pressure, are of particular importance. The stability states are then verified one by one for each shell segment of the constant thickness $t_{i}$. The design resistance for each segment is determined as buckling stresses obtained by multiplying stress values corresponding to the material yield strength and the buckling reduction factor $\chi_{i}$. The buckling reduction factor is a function of the relative slenderness $\lambda_{\theta, \mathrm{i}}$ of the shell segment, which in turn is connected with the elastic critical buckling $\sigma_{\theta, R c r, i}$. To calculate critical circumferential stresses for each segment, the shell composed of a few segments is replaced with the equivalent shell of a length and constant thickness calculated in accordance with the Appendix D to the standard (PN-EN 1993-1-6, 2009). In the discussed case, in which the shell had two stiffening rings, the shell was divided into two analytical models: the first one covered part of the shell between the primary wind girder and the secondary stiffening ring, the second one covered the shell from the secondary ring to the bottom edge of the shell.

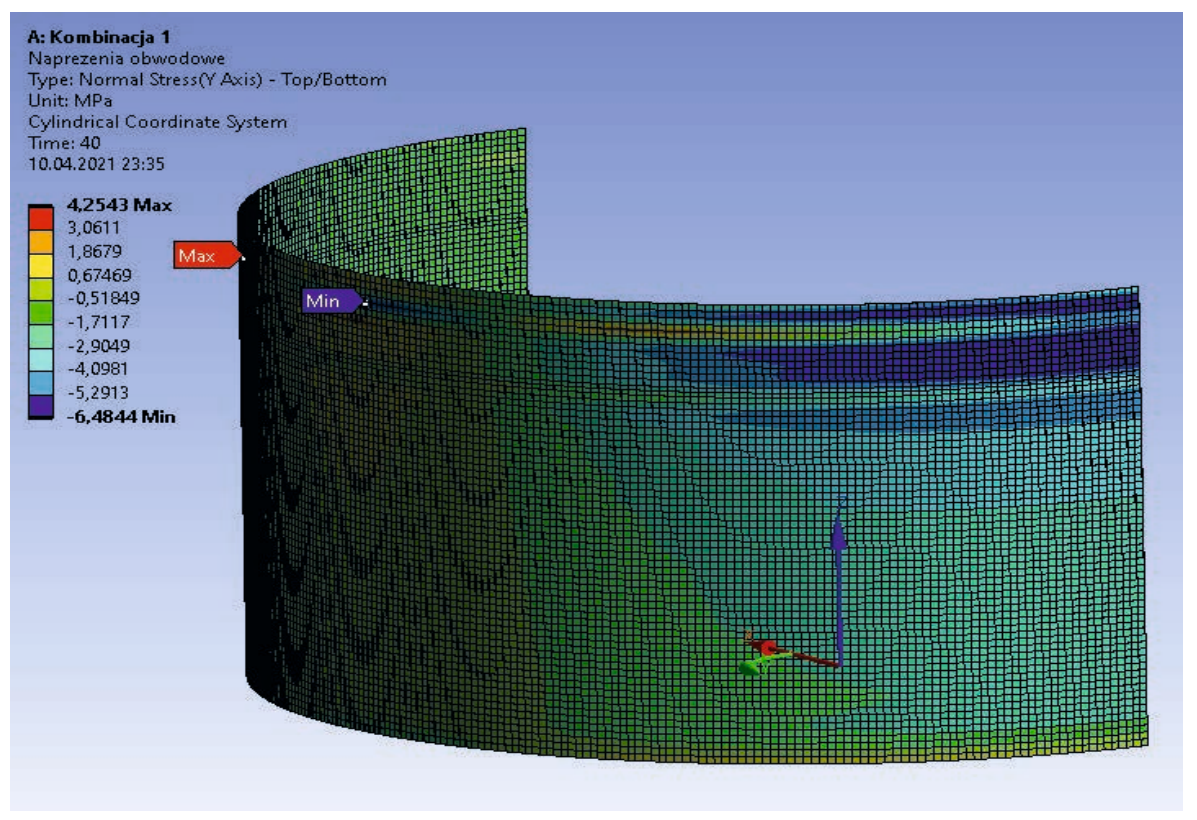

The stress distribution around the shell under the design (reference) load was determined from the LA. Figure 3 shows that circumferential compressive membrane stresses $\sigma_{\theta, \mathrm{Ed}}$ was mainly exerted on the windward side of the shell, in the zone of wind pressure (cf. Fig. 2). The recommendations of the ECCS guidelines (ECCS, 2008) to determine key circumferential stresses used to verify the stability conditions were applied. According to these guidelines, stresses exerted in the zone of length $l=2(0.5 D \cdot t)^{0,5}$, adjacent to the edge of the shell with stiffening components, could be neglected in the buckling analyses. It should be mentioned that local stresses in the above zones could lead to the overrated stress intensity in the shell areas, which were de facto protected against local buckling. Local buckling effects were identified in the examined shell area near the primary stiffening ring and the secondary stiffening ring, and also next to the fixed bottom edge of the shell. The determined zones were also taken into account for verifying interaction-relevant conditions for stability, for which the zone length was determined in accordance with the standard (PN-EN 1993-1-6, 2009).

The calculations indicated the exceeded resistance of the shell at rings Nos. 10 and 9 (Fig. 4). The highest levels of stress intensity of these rings in the meridional and circumferential directions, determined form the interaction-relevant conditions for compressive stresses and shear stresses, were 133 and
Fig. 3. Map of circumferential stresses exerted on the tank shell (own study) 
Fig. 4. Stress intensity level of the shell obtained from the stress design (own study)

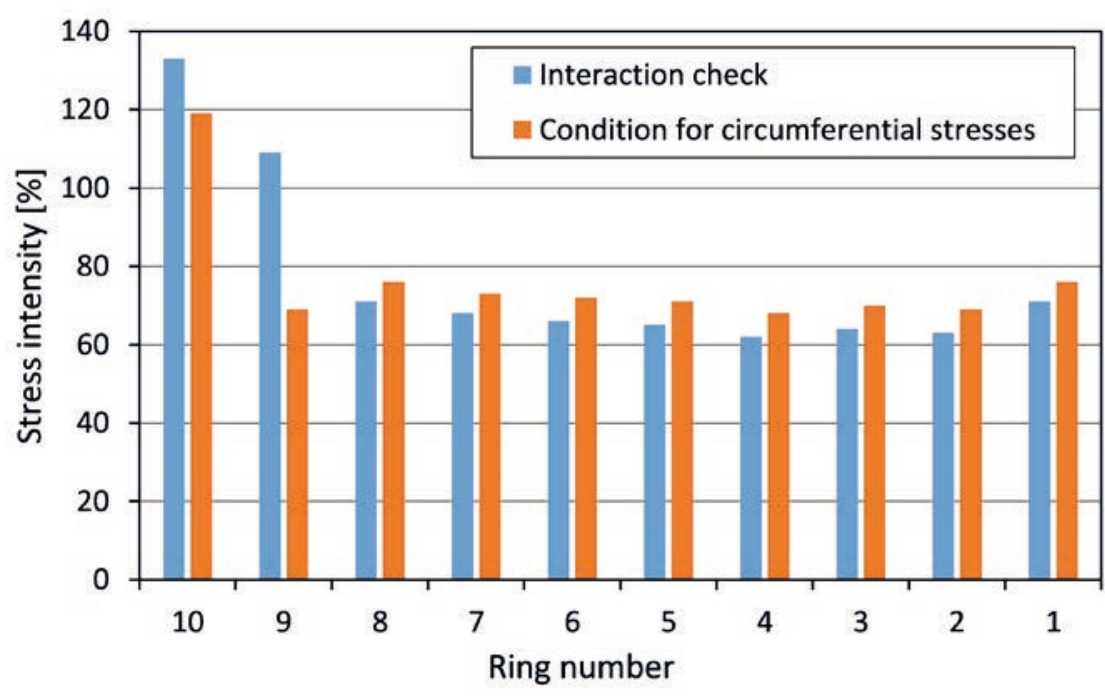

$109 \%$ respectively. These exceeded values were found in the areas, where the highest compressive stresses exerted circumferentially were registered. It should be also mentioned that stress intensity of the ring No. 10, obtained from the condition relating only to the circumferential compressive stresses, was $119 \%$.

\section{Stability verification using the MNA-LBA procedure}

Verification of the shell stability using the MNA-LBA procedure means checking the condition under which the shell can be regarded as stable provided that the design buckling resistance ratio $r_{R d}$ - one for the whole shell - is not lower than unity $\left(r_{R d} \geq 1\right)$. The ratio $r_{R d}$ is determined as the product of the plastic reference resistance ratio $r_{R p l}$ and the buckling factor $\chi_{\mathrm{ov}}$, reduced by the partial factor $\gamma_{\mathrm{M} 1}$. The ratio $r_{R p l}$ indicates the highest value of the design (reference) load multiplier in the state of development of the plastic collapse mechanism of the shell. This ratio should be determined from the materially non-linear analysis (MNA) based on the assumption of the small deflection theory or can be determined using the simplified analytical-based method when the MNA can be problematic. The buckling reduction factor $\chi_{\mathrm{ov}}$ is a function of the relative slenderness of the shell $\lambda_{\text {ov }}$ determined from:

$$
\overline{\lambda_{o v}}=\sqrt{\frac{r_{R p l}}{r_{R c r}}}
$$

where:

$r_{R c r}$ is the critical buckling resistance ratio, $r_{R p l}-$ as specified above.

The ratio $r_{R c r}$ is determined from the linear bifurcation analysis (LBA) conducted for an ideal shell, that is, free of any imperfections in a stress state determined from the LA. This ratio is usually determined as the lowest factor of the bifurcation load. The term "usually" means that a designer should be sufficiently experienced in assessing the obtained shell buckling modes to select the adequate eigenvalue. The key element is to select the eigenvalue and the associated buckling mode, which are the base to select the buckling parameters, for which the corresponding buckling resistance is the lowest (ECCS, 2008).

To summarize, it can be stated that the key objective of numerical analyses for the MNA-LBA design procedure is to determine the ratios $r_{R p l}$ and $r_{R c r}$. The procedure for calculating the buckling ratio $\chi_{\mathrm{ov}}$ is similar to the procedure for designing by the stress state analysis, but this ratio is determined for the whole shell instead of its subsequent segments as in the case of the stress design. 


\subsection{Determining the critical buckling resistance ratio}

The linear bifurcation analysis (LBA) was performed to determine the critical resistance ratio $r_{R c r}$ for the analysed shell. This analysis was conducted at the stress state of the shell obtained from the LA which had been performed to verify the stability for the stress design. Following the ECCS recommendations (ECCS, 2008), 10 first buckling modes and the associated eigenvalues $r_{1 \div 10}$ were determined. The four selected buckling modes are presented in Fig. 5. These modes were typical for three different forms of local buckling. Buckling deformations for all determined modes were found in the shell area exposed to external wind pressure (cf. Fig. 2). These deformations were characteristic for local buckling caused by compressive membrane stresses exerted circumferentially as a result of wind effects on an empty tank (Zhao, Lin, 2014; Chen, Rotter, 2012; Uematsu, Yamaguchi, Yasunaga, 2018; Chrysanthos, Georgios, Konstantinos, 2015; Godoy, 2016). Buckling waves were formed in the shell between the primary wind girder and the secondary stiffening ring (modes 1-3, 5 and 7), between the secondary stiffening ring and the bottom edge (modes 4-6 and 8), or simultaneously in both areas (modes 9 and 10). It is worth mentioning that deformations of the shell which were observed for the first buckling mode with the lowest bifurcation load ratio, were found in the shell area for which resistance values were significantly exceeded at the stress design (Fig. 4). Thus, the eigenvalue $r_{1}=2.53$ could be considered to indicate the critical resistance ratio $r_{R c r}$ of the shell.
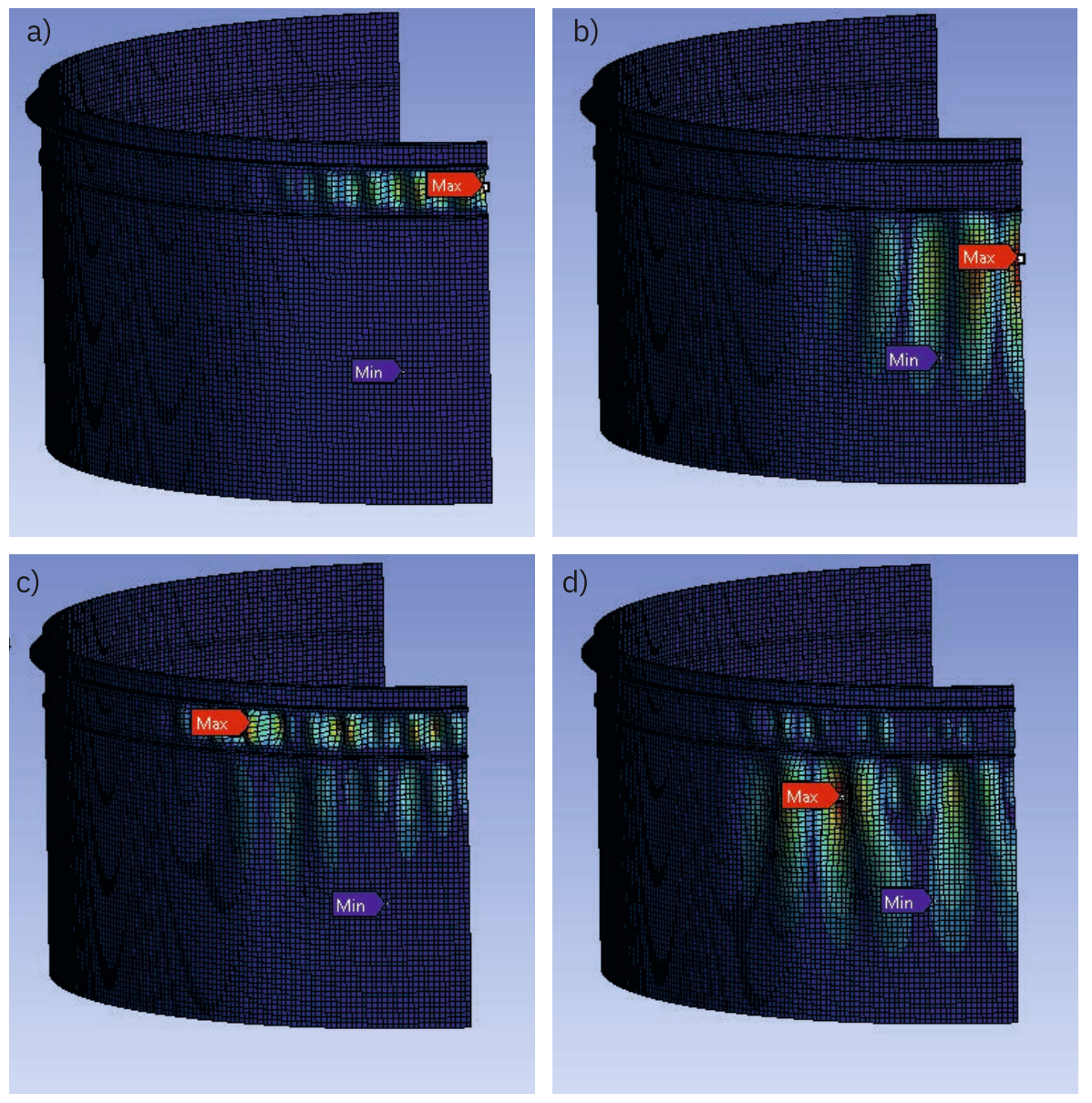

Fig. 5. Selected buckling modes of the shell determined by the LBA: a) $1^{\text {st }}$ mode $-r_{1}=2.53$, b) $4^{\text {th }}$ mode $-r_{4}=2.71$, c) $9^{\text {th }}$ mode $-r_{9}=$ $3.04, d$ ) $10^{\text {th }}$ mode $-r_{10}=3.06$ (own study) 


\subsection{Determining the plastic reference resistance ratio}

Based on the standard (PN-EN 1993-1-6, 2009) recommendations, the plastic reference resistance ratio $r_{R p l}$ should be determined from the materially non-linear analysis (MNA). However, this standard does not specify any particular calculation algorithm dedicated to this analysis. In this context it should be mentioned that one of the main objectives of the MNA is to calculate the mechanism of plastic limit load. The arc length increment method is usually used in increment computations in the FEM determination (Doerich, 2011). This method is particularly useful when the plastic mechanism resistance requires the development of yielding zones at some locations on the shell surface and thus, it can be difficult to identify precisely the moment of developing the plastic collapse mechanism (Stowiński, 2019). But the reliable and quality results from the arc-length analysis require an "operator" who is skilled and experienced in the field of selecting the analysis parameters. Such calculations are usually laborious, which is particularly disruptive when the analysis parameters have to be modified and the computations have to be resumed. Due to these inconveniences, the MNA was performed for the analysed shell in a simplified way using the incremental Newton-Raphson (N-R) method which, as opposed to the previously mentioned method, consists in controlling the displacement of a given mesh point, and not the arc length increment (Bathe, 1982). This method seems to be more accessible in the design than the arc-length method. However, the N-R method can be used for the analysed problem when at least an approximate concept has been formulated for a possible form of the plastic collapse mechanism and the load values corresponding to the development of this mechanism.

\subsubsection{Standard-based estimation}

In order to obtain information on the possible location of the plasticization zone and the magnitude of the load multiplier accompanying the development of this zone, the relationship from the standard (PN-EN 1993-1-6, 2009) was used mapped by means of membrane stresses - allowing to roughly determine the value of the plastic reference resistance ratio:

$$
r_{R p l}=\frac{f_{y k}}{\sqrt{\sigma_{x, \mathrm{Ed}}^{2}-\sigma_{x, \mathrm{Ed}} \cdot \sigma_{\theta, \mathrm{Ed}}^{2}+3 \tau_{x \theta, \mathrm{Ed}}^{2}}}
$$

where:

$f_{\mathrm{yk}}$ - characteristic yield strength of the material - adopted to be equal to $235 \mathrm{MPa}$, other notations - as specified above.

It should be mentioned that this relationship (2) can be used to estimate the ratio $r_{R p l}$ when it is difficult to perform the MNA (PN-EN 1993-1-6, 2009). This relationship was utilized in accordance with the standard for three points of the shell, at which the design resultants of buckling relevant membrane stresses, that is $\sigma_{\mathrm{x}, \mathrm{Ed}}, \sigma_{\theta, \mathrm{Ed}}$ and $\tau_{\mathrm{x} \theta \mathrm{Ed}}$, reached the maximum values. These points were at different places of the shell as illustrated in Fig. 6 (the stress maps show only part of the shell below the primary stiffening ring to make it clearer). Following the standard recommendations (PN-EN 1993-1-6, 2009), the lowest value of the ratio calculated at three identified points was the safe estimation of $r_{R p l}$. The ECCS guidelines (ECCS, 2008) suggest that the desired situation for evaluating the relative slenderness of the shell is when the point location, for which the plastic reference resistance ratio is determined, coincides with the zone of buckling deformations obtained from the LBA. The lowest ratio $r_{R p l}=38.5$ was determined by analysing a point on the shell surface, at which yielding was observed at dominant compressive stresses in the circumferential direction (Fig. 6b). This point was located along the shell length between the primary wind girder and the secondary stiffening ring. It can be noted that deformations 


\section{::: technical

a)

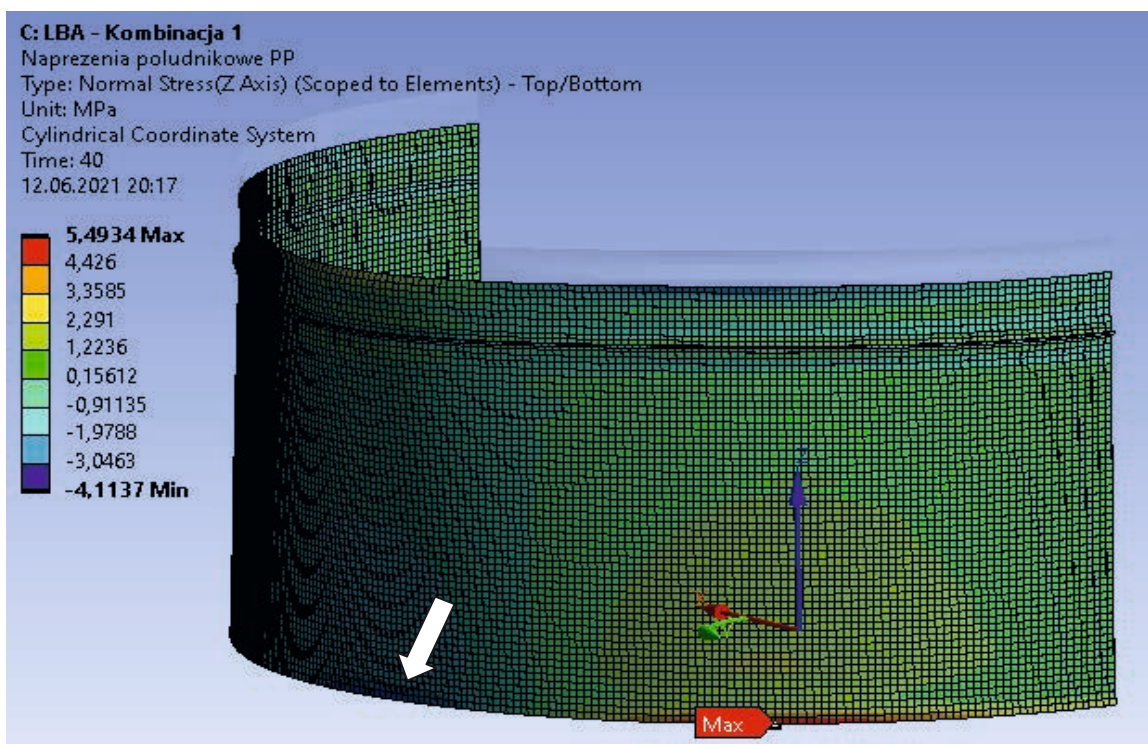

b)

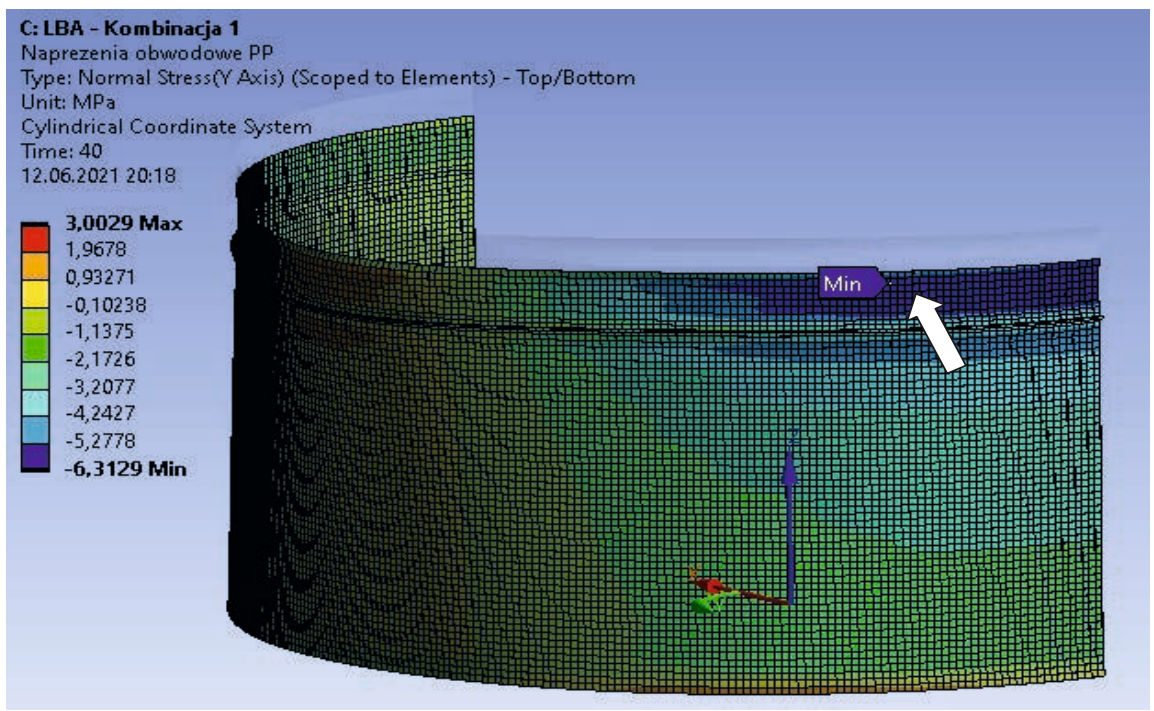

c)

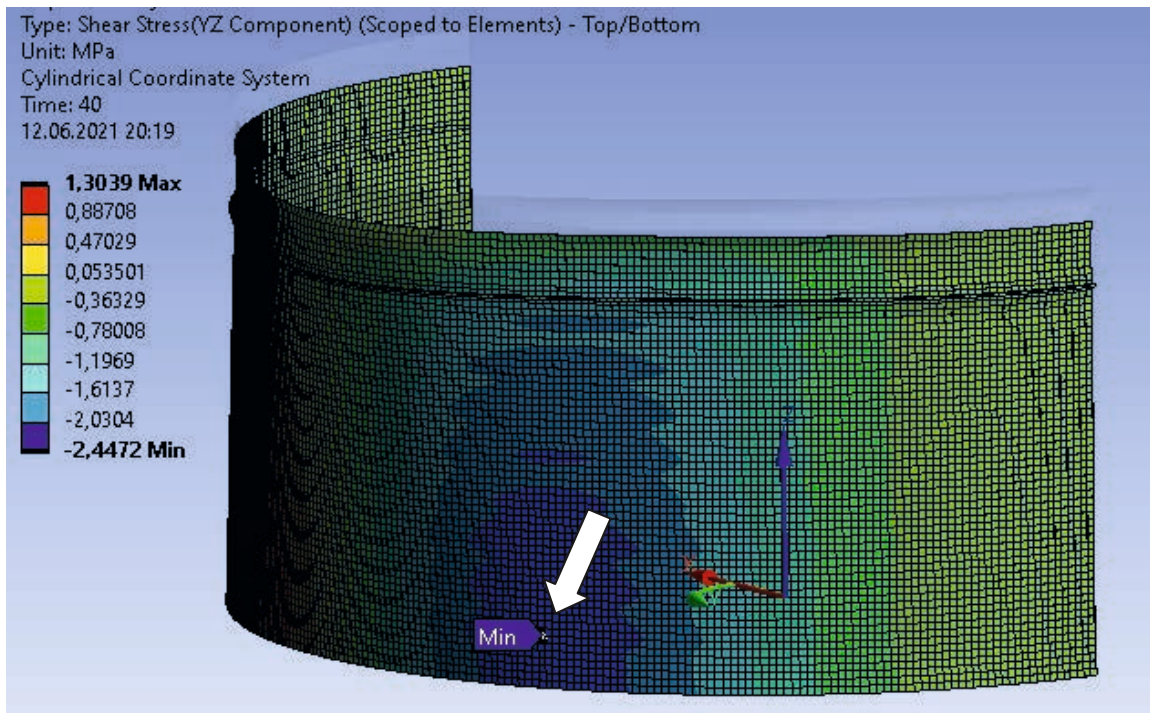

Fig. 6. Approximated location of points with maximum values, reliable at buckling, components of membrane stresses: a) $\sigma_{x, E d}$, b) $\sigma_{\theta, E d}$, c) $\tau_{x \theta, E d}$ (own study) 
accompanying the first mode of buckling were recorded in the same area of the shell (Fig. 5a). The recommendations concerning procedures when the yielding zone does not coincide with the zone of buckling deformations are discussed in (ECCS, 2008).

\subsubsection{MNA analysis}

The materially non-linear analysis was conducted in the Static Structural module of the Ansys software. An elastic-perfectly plastic model of the material was used for the calculations. The calculations were performed in an iterative mode by increasing the load ratio $r$ in each subsequent calculation cycle beginning from the value obtained from the relationship below:

$$
r_{i n i}=\frac{f_{y}}{\sigma_{\mathrm{Ed}, \text { max }}}
$$

where:

$\sigma_{E d, \max }$ - maximum equivalent stress acc. to the Huber-Mises-Hencky theory, recorded for the reference load $(r=1)$ based from the LA; these stresses were recorded at the interface between the shell and the primary stiffening ring at $\theta \approx 83^{\circ}$.

Knowing the ratio $r_{i n i}=32$ that specified the yield initiation in the shell and the ratio $r_{R p l}=38.5$ estimated from the relationship (2), the ratio value $r$ was increasing every 0.5 or 1 in the subsequent calculation cycles and the number of load increments was modified while observing the development of the yielding zone on the tank shell. For the ratio $r=36$, the first yielding zone was observed close to the point, at which the stresses $\sigma_{\mathrm{Ed}, \max }$ had been previously recorded, and this zone covered a significantly small area of the shell above the primary stiffening ring (Fig. 7). When the ratio increased to $r=37$, the next yielding zone was developed on the windward side of the shell between the stiffening rings. This zone was increasing with the load increasing to $r=40$ and was accompanied by a significant increase in permanent deformations on the windward side of the shell (Fig. 7). When the load increase exceeded $r=40$, there was a significant increase in the non-linear strains already recorded in the yielding zone. Hence, the observed response of the system was considered to be the plastic mechanism resistance of the shell. The area of recorded plastic strains also covered the point, at which the value of plastic resistance reference ratio was determined from the equation (2). Considering the evaluation of the relative slenderness of the shell, location of the discussed yielding zone coincided with the area of buckling for the first mode of buckling determined from the LBA (Fig. 5a).

The plastic reference resistance ratio $r_{R p l}$ was determined by the graphical method using the modified Southwell plot (ZZS). Application of this method to determine plastic resistance of shells was described, inter alia, in the paper (Holst, Rotter, Münch 2007). The ZZS plot illustrates the relationship between the ratio $r / u$ - on the $\mathrm{x}$-axis and $r$ on the $\mathrm{y}$-axis, where $u$ is the displacement recorded at the chosen point of the shell. The basic problem about using the modified Southwell plot consisted in choosing the proper point, for which this relationship was to be developed. This point should be located in the area of plastic strains associated with the plastic collapse mechanism. The procedure of choosing this point can be troublesome when the plastic mechanism requires the development of plastic strains at some points on the shell surface (Stowiński, Piekarczyk 2019). In case of the discussed shell with a wide yielding zone, which was relatively simple to be identified, the point for analysis was in the zone with the greatest resultant displacement (and the greatest plastic strain) at $r=40$ (Fig. 7). The ZZS plot for this point is illustrated in Fig. 8. The relationship was initially vertical which described the elastic behaviour of the shell material. Progressive yielding of the shell at the test point was described by the second, nearly horizontal, part of this relationship. The intersection point between 


\section{口:: technical
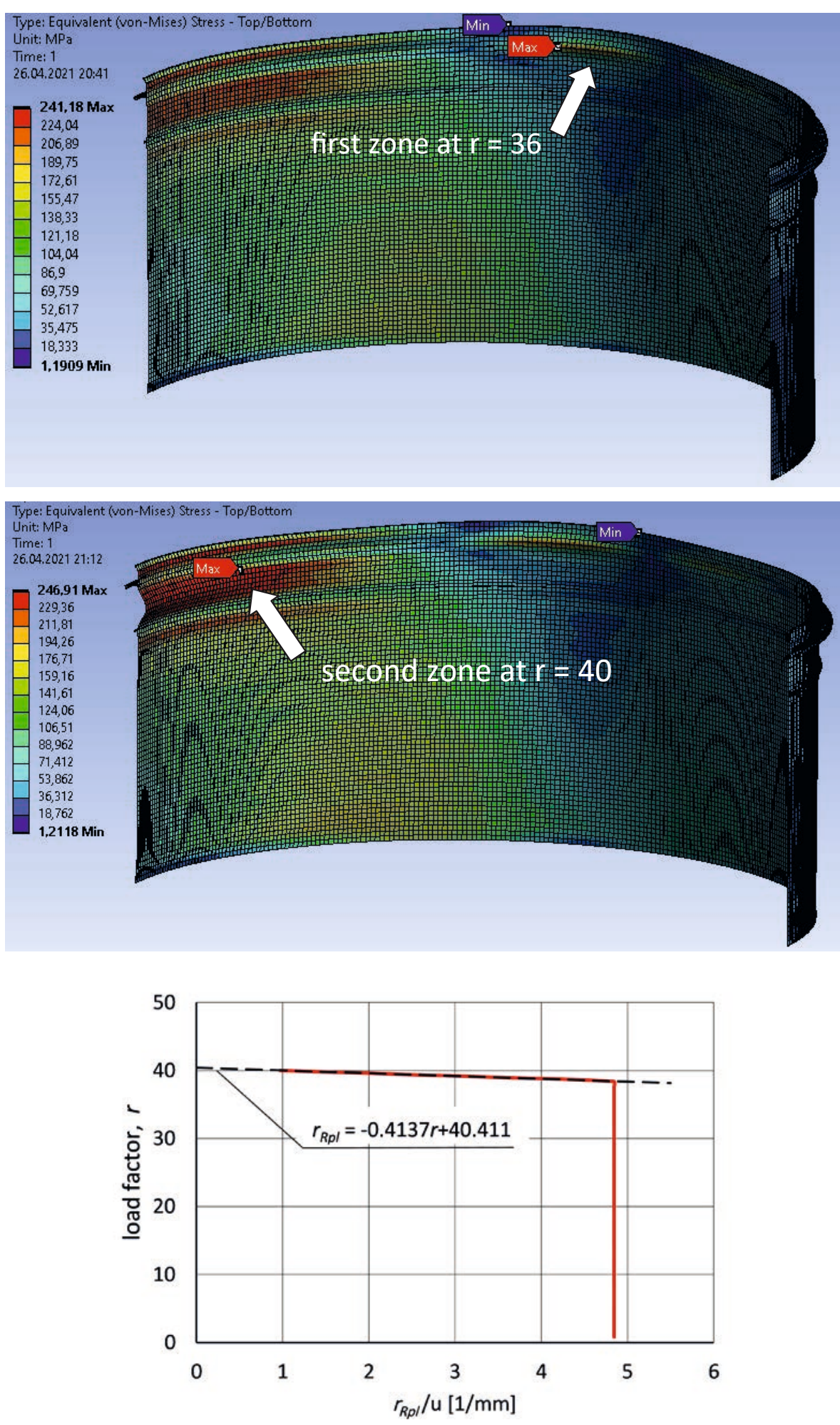

the tangent line (dashed line in Fig 8) to the second part of the curve and the $\mathrm{y}$-axis indicated the value of plastic resistance. The factor $r_{R p l}$ determined as above was equal to 40.4. It should be noted that the moment of transition from first to second part of the curve was equal to the ratio $r=38.4$, which was very close to the value determined form the standard relationship (2).
Fig. 7. Development of plastic zones in the shell (own study)

Fig. 8. Modified Southwell plot for the analysed shell (own study) 


\subsubsection{Verification of stability condition}

The relative slenderness was assessed from the relationship (1) using ratios $r_{R c r}=2.53$ and $r_{R p l}=40.4$ determined by the LBA and MNA respectively. The determined slenderness $\lambda_{\text {ov }}=4.0$ was found to be definitely greater than the reference slenderness, due to which the shell was classified as the system subjected to local buckling in the elastic range. The following condition was defined as the end result of further calculations made in accordance with the standard (PN-EN 1993-1-6, 2009):

$$
r_{R d}=1.5>1.0
$$

which demonstrated that the shell was stable within a range of the applied load. The stress intensity level of the shell determined by the MNA-LBA procedure was $67 \%\left(\left(1 / r_{R d}\right) \cdot 100 \%\right)$.

\section{Discussion of results and conclusions}

A comparison of the results obtained by the design methods recommended in the standard (PN-EN 1993-1-6, 2009) demonstrated a significant discrepancy in the stress intensity levels of the discussed shell determined by these methods. Design by the stress state analysis demonstrated the shell resistance was locally exceeded by $33 \%$. On the other hand, the MNA-LBA procedure indicated a $33 \%$ resistance reserve for the analysed system. The reasons could be mainly attributed to different assumptions of design concerning the stress states which were the base for determining critical stresses at elastic buckling. The stress design covered the critical stresses at the elastic buckling $\sigma_{\theta, R c r}$, which were adequate for cylindrical steel shells exposed to the uniformly distributed external pressure (Timoshenko, Gere, 1963). This load distribution resulted in compressive stresses of constant values which were circumferentially exerted on almost the whole shell surface. Numerous faults in tanks with the stress state as described above (Supernak, Ziótko, 2013). showed that such a stress state was among the most "unfavourable" load states for cylindrical steel shells. In spite of external pressure acting on the substantial part of the shell circumference, the zone of wind pressure on the windward side of the shell - which was critical for assessing its stability - was within the angle $\theta \leq 60^{\circ}$ (Fig. 2). The distribution of wind pressure was non-linear. The stress state resulting from the load, that is, the zone of critical compressive stresses exerted circumferentially $\sigma_{\theta, \mathrm{Ed}}$ enclosed to the shell part of the windward side, ensured noticeably better stability than the load state of uniform external pressure. This more "favourable" stress state was used to determine eigenvalues of the system by the linear bifurcation analysis (LBA) employed in the MNA-LBA design procedure. The results indicated that the buckling stresses $\sigma_{\theta, \mathrm{LBA}}$ determined by the LBA constituted $276 \%$ of critical stresses $\sigma_{\theta, R c r}$ determined by the standard recommendations (PN-EN 1993-1-6, 2009) for the most stressed ring No. 10. However, in defence of the stress approach, it should be pointed out that the conservative assumption regarding the method of calculating $\sigma_{\theta, R c r}$ allows for the inclusion, by means of a unified and uncomplicated calculation procedure, of a wide spectrum of different load cases for cylindrical shells (ECCS, 2008).

The satisfactory convergence of values of the plastic reference resistance ratios determined from the analytical relationship (2) and the materially non-linear analysis (MNA) is worth noting. The ratio $r_{R p l}$ obtained from the relationship (2) constituted $95 \%$ of the value determined by the MNA using the modified Southwell plot (Fig. 8). A difference in these both values was caused by determining the ratio $r_{R p l}$ in the first case - for yielding in single shell point and in the second case - after developing the plastic collapse mechanism of the shell. The obtained result indicated that the determination of the plastic reference 
resistance ratio from the simplified standard relationship, which was based on the results from the linear analysis, was sufficient to assess the stability of the considered shell.

The obtained results confirmed the relevance of the MNA-LBA procedure for assessing the shell stability of the open cylindrical tank. The authors hope that this paper will contribute to more popular application of this procedure in the process of designing cylindrical tanks. 


\section{References}

Bathe, H.J. (1982). Finite element procedures in engineering Analysis. New Jersey: Prentice-Hall.

Chen, L., Rotter, J.M. (2012). Buckling of anchored cylindrical shells of uniform thickness under wind load. Engineering Structures, 41, 199-208.

Chrysanthos, M., Georgios, A.B., Konstantinos, D.T. (2015). Numerical evaluation on the shell buckling of empty thin-walled steel tanks under wind load according to current American and European design codes. Thin-Walled Structures, 95, 152-160.

Doerich, C., Rotter, J.M. (2011). Accurate determination of plastic collapse loads from finite element analyses. Journal of Pressure Vessel Technology, 133.

ECCS TC8 TWG 8.4 (2008). Shells - Buckling of steel shells - European design recommendations - 5th edition. Portugal: European Convention for Constructional Steelwork.

Godoy, L.A. (2016). Buckling of vertical oil storage steel tanks: review of static buckling studies. Thin-Walled Structures, 103, 1-21.

Holst, J.M.F.G., Rotter, J.M., Münch, M. (2007). Failure criteria for shells on local brackets. In H.R. Drew, S. Pellegrino (Eds.), New Approaches to Structural Mechanics, Shells and Biological Structures (pp. 315-328). London: Kluwer Academic Publishers.

Iwicki, P., Tejchman, J., Chróścielewski, J. (2014). Dynamic FE simulations of buckling process in thin-walled cylindrical metal silos. Thin-Walled Structures, 84, 344-359.

Król, M. (2021). Weryfikacja stateczności ptaszcza zbiornika na ropę naftowa z wykorzystaniem podejścia naprężeniowego oraz procedury wymiarowania MNA-LBA (master thesis). Politechnika Śląska (manuscript).

PN-EN 1990 (2004). Eurokod: Podstawy projektowania konstrukcji. Warszawa: PKN.

PN-EN 1993-1-1. (2006). Eurokod 3: Projektowanie konstrukcji stalowych Część 1-1: Reguty ogólne i reguty dla budynków. Warszawa: PKN.

PN-EN 1993-1-6. (2009). Eurokod 3: Projektowanie konstrukcji stalowych-Część 1-6: Wytrzymatość i stateczność konstrukcji powtokowych. Warszawa: PKN.

PN-EN 1993-4-1. (2009). Eurokod 3: Projektowanie konstrukcji stalowych Część 4-1: Silosy. Warszawa: PKN.

PN-EN 14015. (2010). Specyfikacja dotyczaca projektowania i wytwarzania na miejscu zbiorników pionowych o przekroju kotowym, z dnem płaskim, naziemnych, stalowych spawanych, na ciecze o temperaturze otoczenia i wyższej. Warszawa: PKN.

Rotter, J.M. (2011). Shell buckling design and assessment and the LBA-MNA methodology. Stahlbau, 80(11), 791-803.

Stowiński, K., Piekarczyk, M. (2019). FEM determination of the plastic limit load for cylindrical shells. Technical Transactions, 12, 151-162.

Supernak, E., Ziółko, J. (2013). Podciśnienie w zbiornikach - Wnioski ze zdarzeń w ostatnich latach. In XXVI Konferencja naukowo-techniczna Awarie Budowlane (pp. 589-598). Szczecin.

Timoshenko, S.P., Gere, J.M. (1963). Teoria stateczności sprężystej. Warszawa: Arkady.

Uematsu, Y., Yamaguchi, T., Yasunaga, J. (2018). Effects of wind girders on the buckling of open-topped storage tanks under quasi-static wind loading. Thin-Walled Structures, 124, 1-12.

Zhao, Y., Lin, Y. (2014). Buckling of cylindrical open-topped steel tanks under wind load. Thin-Walled Structures, 79, 83-94.

Żyburtowicz, M. (1966). Album rysunków konstrukcji stalowych. Warszawa: Arkady. 


\section{Weryfikacja stateczności płaszcza zbiornika cylindrycznego z wykorzystaniem podejścia naprężeniowego oraz procedury MNA-LBA}

\section{Streszczenie}

W artykule przedstawiono przebieg i rezultaty procedury weryfikacji stateczności płaszcza zbiornika cylindrycznego na ropę naftową, z dachem pływającym, obciążonego wiatrem. Wykorzystano dwie z rekomendowanych przez normę PN-EN 1993-1-6 metod wymiarowania, tj. wymiarowanie na podstawie stanu naprężenia oraz procedurę MNA-LBA. Przedstawiono sposób wyznaczania wskaźnika nośności krytycznej z liniowej analizy bifurkacyjnej (LBA) oraz wskaźnika nośności plastycznej z analizy fizycznie nieliniowej (MNA). Porównanie ze sobą wyników otrzymanych przy zastosowaniu wskazanych metod projektowania ujawniło znaczące rozbieżności w poziomach wytężenia analizowanej powłoki. Przy zastosowaniu metody wymiarowania na podstawie stanu naprężenia wykazano przekroczenie nośności powłoki o 33\%, natomiast rezultaty procedury MNA-LBA wskazały na 33\% rezerwy nośności analizowanego układu.

Stowa kluczowe: procedura MNA-LBA, zbiornik stalowy, wyboczenie, zniszczenie plastyczne, obciążenie wiatrem 